Economics

GROWTH OF PRODUCTION IN FISHERIES

IN RELATION TO INVESTMENTS ON LAND, INVESTMENTS

IN VESSELS AND TO LABOUR

ZALEŻNOŚĆ WZROSTU PRODUKCJI

OD INWESTYCJI LĄDOWYCH I INWESTYCJI NA FBOTE, ORAZ ZATRUDNIENIA W PRZEMYŚLE RYBNYM

\author{
From Department of Economics \\ Head: Prof. Dr. Andrzej Niegolewski
}

Effective investments, or their influence on growth of production, can not be considered in qualitative or quantitative aspects only. The inter substitution of the particular factors, as constituents of a production function determines the basis for the proper allocation of funds.

\title{
INTRODUCTION
}

The presented work deals with the analysis of factors, which determine the growth of production in fisheries. It is also aimed to examine how the production is influenced by the investments on land, the investments in vessels, and the labour.

Such analysis should define the productivity of particular factors and the degree of their intersubstitution. The obtained results represent the estimating materials for proper allocation of investments and initial further research in subject of the optimal proportions of investments in fisheries.

The theory and methods applicable for correctestimation of the production function are widely represented in a world economical literature and in some Polish economical works ${ }^{1}$ )

\footnotetext{
1) Compare: Pajestka J. - Employment and investment $\mathrm{v} / \mathrm{s}$ growth of production. Warsaw 1961. Dunajewski H. - Structure and application of Cobb-Douglas function. "Economist" 3/1962. Bosiuk J. - Maciejewski W. Piaszczyński W. - Function of production for Poland during the 1955 1/65. Foreign Trade Conjuncture and Prices Research Institute. Selected works 1968.
} 


\section{FUNCTION OF PRODUCTION}

As a model of the production function is adapted here the Cobb-Douglas model, as the most applicable in an assessment of relation between the production factors and production quantity. The results of works of the many authors listed under "REFERENCES", proved that, an application of Cobb- Douglas function is very conclusive in estimating the relation between the production quantity and the change of factors arrangement.

The conclusions drawn on such grounds may represent a very vital element of the economical analysis.

To determine the interrelation of production quantity and the investments on land, in vessels and labour in fisheries, the following function is applied:

$$
Z=A x_{1} \alpha x_{2} \beta x_{3} \gamma
$$

where: $Z$ = value of production

$x_{1}=$ investments on land

$x_{2}^{1}=$ investments in vessels

$x_{3}^{2}=$ labour

$\AA=$ constant

$\alpha, \beta, \gamma=$ respective coefficients of production elasticity.

The statistical tests as an estimation prove that, the interrelation of investments, labour and production can be expressed by the above function. Thus, its characteristics allow for an analysis of the economical relation and for some theoretical and practical conclusions.

The function in question possesses some general characteristics, which may by expressed as:

1) $\alpha, \beta, \gamma$ - coefficients of production elasticity, which express the relative ratio of production growth to an increase of investments.

In the applied function, the elasticity coefficients of production for the particular factors are constant; thus, the elasticity is equal at every point.

Denoting the production elasticity in relation to investments by $e_{i}$ (while $\dot{i}=1,2$ or 3 and is relating to the particular factor), we obtain:

$$
e_{i}=\frac{x_{i}}{Z} \cdot \frac{d z}{d z}=\frac{x_{1}}{Z} \cdot f^{\prime} x_{i}
$$

what in direct conversion of function, gives:

$$
e_{i}=\alpha \quad e_{2}=\beta \quad e_{3}=\gamma
$$

The total of production elasticity coefficients:

$$
S=\alpha+\beta+\gamma
$$

determines degree of homogeneity of function, and thus, when: $S=1$, denotes constant scale of growth 
$\mathrm{S}<1$, denotes descreasing scale of growth

$S>1$, denotes increasing scale of growth.

Assuming that all the investments shall be increased twice, the production increase will be twofold in case of $S=1$, or less than twofold in case of $S<1$, or more than twofold in case of $S>1$.

2) For $x_{1}$ (investments on land), the average productivity ma be expressed as:

$$
\frac{z}{x_{1}}=\frac{A x_{1}^{\alpha} x_{2}^{\beta} x_{3} \gamma}{x_{1}}=A x_{1}^{\alpha-1} x_{2}^{\beta} x_{3}^{\gamma}
$$

3) Final productivity for factor $x$ is expressed by the formula:

$$
\frac{I Z}{I x_{1}}=A \alpha x_{1}^{\alpha-1} x_{2}^{\beta} x_{3}^{\gamma}
$$

4) The increasing rate of production, conditioned by the increase of a given factor, is determined by the second derivative, as per formula (for factor $x_{1}$ ).

$$
\frac{d^{2} z}{d x_{1}^{2}}=A \alpha(\alpha-1) x_{1}^{\alpha-2} x_{2}^{\beta} x_{3}^{\gamma}
$$

Similiar formula shall express the increasing rate of production for the remaining factors $x_{2}$ and $x_{3}$.

5) For determination of the factors intersubstitution rate, the quantity of production is assumed to be constant. The rate of substitution between the factor $x_{1}$ and $x_{2}$, (i.e. investments on land and investments in vessels), which is indispensable for maintenance of a defined production level, is expressed by the formula:

$$
\frac{d x_{1}}{d x_{2}}=\frac{\frac{I z}{I x_{2}}}{\frac{I z}{I x_{1}}}=\frac{\alpha x_{2}}{\beta x_{1}}
$$

It is apparent from the formula, that the substitution rate of factors depends entirely on their interrelation and not on their absolute quantity. The elasticity of the factors substitution rate for the assumed function, is constant and equals to unity.

\section{STATISTICAL DATA}

Following materials were applied for analysis of the assumed function:
a) statistical data relating to the gross output at producer's prices;
b) total investments in dispartion for vessels and land disbursement;
c) labour. 
No investments on mereting are included. The data comprises the activities of state interprices, such as, fishing, processing and fish-port services, as recorded "by Central Board of Fishings" and released by "Ministry of Navigation" for the period of 1958-1967, and represent:

ad a) - Gross output at producer's prices, i.e. - the total value of goods and services produced by industrial enterprises amalgamated under "Central Board of Fisheries" for sales beyond the branch. Not included, are the inter-enterprise turnovers.

ad b) - The total investments born by the industrial enterprises were disparted into vessels and land disbursements. The expendentures on vessels represent the purchases of new ships, or modernization of the old once if paid frominvestmentfunds. Not included, are the social and house-building expendentures, financed from other sources.

ad c) - The given figures comprise the labour in industrial enterprises of "Central Board of Fisheries", with reference to those employed on fishing vessels, mother-ships and remaining in pool.

\section{RESULTS OF ESTIMATION}

The statistical estimation is based on data for the period of 1958-1967, as specified in table 1 in comparative arrangement. Owing to the wide gaps of variations in data, the sequences were balanced by the linear regression method. The estimation was effected by "smallest (Latin) squares method".

Resulting from estimation, are the following values of coeficicients for assumed function (1):

$$
\begin{aligned}
& A=0.254 \\
& \alpha=0,719 \\
& \beta=0.008 \\
& \gamma=0.004
\end{aligned}
$$

The correctness of estimation results is supported by convergence rates "R" and "S"; while $R^{2}$ is the general index of correlation, the $S^{2}$ represents a variancy of particular coefficients denoting degree of the possible deviation.

Convergence rates: $\mathrm{R}^{2}=0.942$

$s_{0}^{2}=0.004$ for coefficient A

$s_{1}^{2}=0.013$ for coefficient $\alpha$

$s_{2}^{2}=0.015$ for coefficient $\beta$

$s_{3}^{2}=0.004$ for coefficient $\gamma$

Table 2 is based on estimation and it specifies the production value, with shown differences between the empirical sequence of basic data and theoritical sequence obtained by estimation. 
$\mathrm{T}$ a b 1 e 1

Arrangement of directives

\begin{tabular}{|c|c|c|c|c|c|c|c|c|c|c|c|}
\hline & Uni.t & 1958 & 1959 & 1960 & 1961 & 1962 & 1963 & 1964 & 1965 & 1966 & 1967 \\
\hline Total investments & thous. & 922.47 & 982,90 & 461.20 & 512.15 & 842.04 & 671.97 & 962.34 & 1221.76 & 1082.54 & 941.24 \\
\hline $\begin{array}{l}\text { Investments on } \\
\text { land }\end{array}$ & thous. & 84.89 & 277.20 & 199.9 & 132.86 & 130,30 & 115.71 & 113.27 & 144.27 & 134.9 & 247.3 \\
\hline $\begin{array}{l}\text { Investments in } \\
\text { vessel }\end{array}$ & thous. & 237.58 & 205.70 & 261.30 & 379.29 & 711.74 & 556.26 & 849.07 & 1077.49 & 947.64 & 694.94 \\
\hline Labour ${ }^{1)}$ & person & 14.252 & 15.856 & 16.435 & 17.324 & 17.767 & 18.696 & $19 \cdot 109$ & 19.839 & $21 \cdot 262$ & 22.179 \\
\hline Production ${ }^{2)}$ & mill & 1.113 & 1.397 & 1.548 & 1.788 & 1.670 & 2.303 & 2.734 & 2.978 & 3.139 & $9 \quad 3.327$ \\
\hline
\end{tabular}

1) Labour in industrial enterprises

2) Production value of industrial enterprises in comparative arrangement. 
Value of production (in million of Zloties)

for period of 1958-1964

\begin{tabular}{|c|c|c|}
\hline Year & Empirical sequence & Theoritical sequence \\
\hline 1958 & 1.11 .3 & 1.090 \\
1959 & 1.397 & 1.335 \\
1960 & 1.548 & 1.567 \\
1961 & 1.787 & 1.790 \\
1962 & 1.669 & 2.001 \\
1963 & 2.303 & 2.214 \\
1964 & 2.734 & 2.418 \\
1965 & 2.977 & 2.618 \\
1966 & 3.139 & 2.814 \\
1967 & 3.327 & 3.020 \\
\hline
\end{tabular}

The statistical analysis of the obtained results, conforms the initial hypothesy that the assumed functional relation is correlative between the investments in vessels, investments on land and labour, and the quantity of production in fisheries.

The obtained results of correlation between empiric and theoretical curves are shown on diagram 1 . Thus, the function of production in fisheries can be expressed as follows:

$$
z=0,254 x_{1}^{0.719} x_{2}^{0.008} x_{3}^{0.004}
$$

The matrix of coefficients, which expresses the correlation of elements, is represented thus:

$\begin{array}{ccccc}x_{1} & x_{2} & x_{3} & z & \\ 1.000 & 0.988 & 0.995 & 0.975 & x_{1} \\ & 1.000 & 0.974 & 0.961 & x_{2} \\ & & 1.000 & 0.964 & x_{3} \\ & & & 1.000 & z\end{array}$

All elements prove a high-degree intercorrelation. The highest correlative coefficient appears between the investments on land and labour, while the lowest one - between quantity of production and investment in vessels. The value of production is mostly correlated with investments on land, thenafter with labour and finally, at the lowest grade, with investments in vessels. 


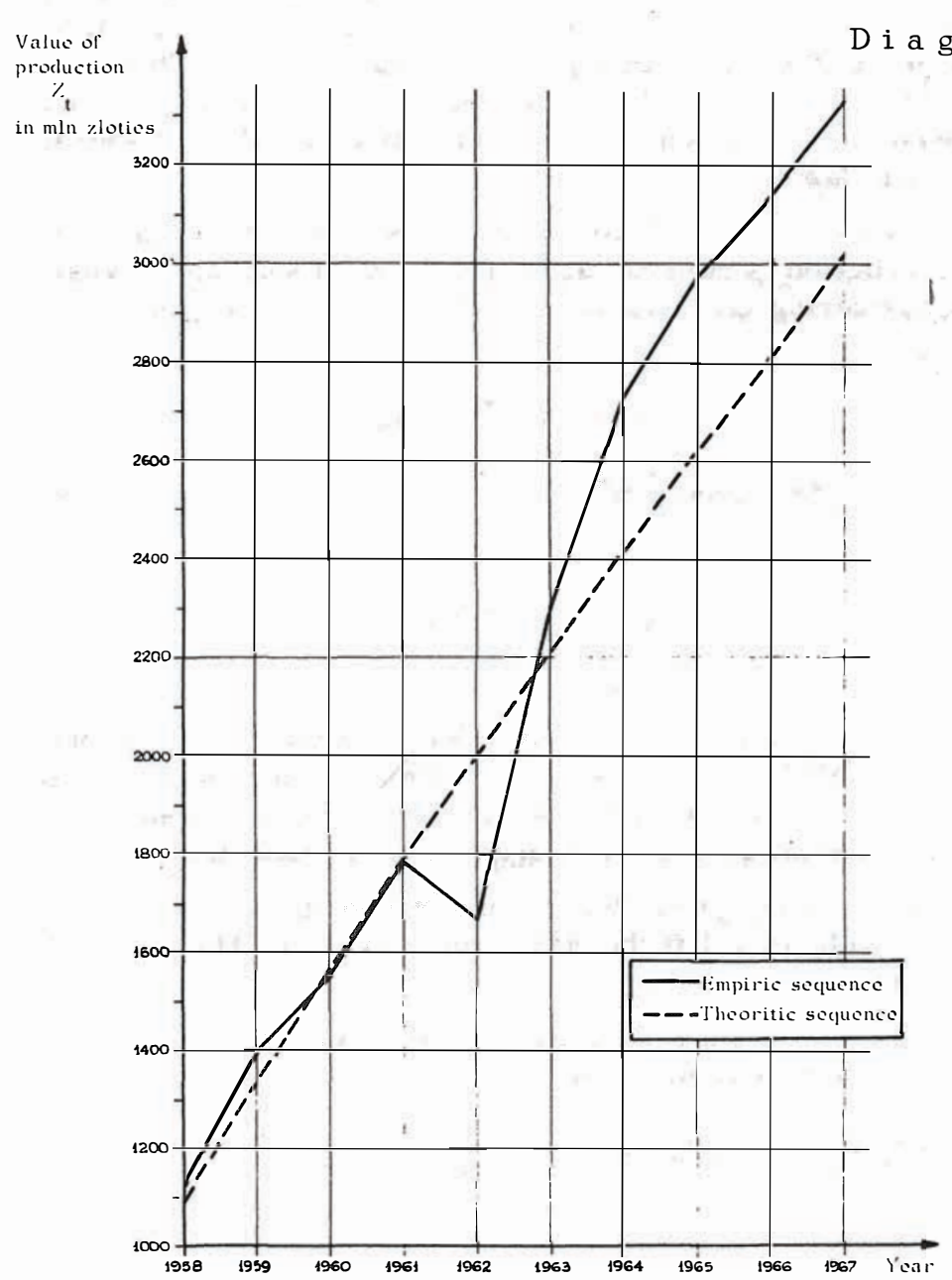

Value of production during the 1958-1967, as per empiric and theoritic sequence

\section{ANALYSIS OF RESULTS}

1. Assuming a high-degree of accuracy of data and the correctness of estimation, the function may be expressed by the formula:

$$
Z=0.254 x_{1}^{0.719} x_{2}^{0.008} x_{3} 0.004
$$

Totals of coefficients

$$
\alpha+\beta+\gamma=0.719+0.008+0.004<1
$$

is less than unity. 
This points to decreasing scale of growth, or it may be said that, the function of production in fisheries is of decreasing scale. Thus, an increase of investments " $n=$ time" will not give the " $n$ - time" increase of production, or an increase of production is less than proportional to disbursements of investments and labour.

From analysis of interrelation coefficients is apparent that, relative increase of production is minimal at increase of labour and investments in vessels. Considering given variancy for coefficient $\beta$ for investments in vessels $\left(s_{2}^{2}\right)$.

$$
\beta=0.008 \pm 0.016
$$

and coefficient $\gamma$ for labour $\left(s_{3}^{2}\right)$

$$
\gamma=0.004 \pm 0.004
$$

may be said that, these coefficients may be even negative or equal to zero.

Under the circumstances, the only semantic is the coefficient of production elasticity relative to investments on land. Considering the prevailing interrelation of coefficients, only the investments on land in assumed conditions have deciding meaning in growth of production in fisheries.

2. Analysis of average productiviness of investments (SP), expressed by formula (3) indicates that the mean productivity of all factors is decreasing in parallel with their increase.

Converting the formula for particular factors, results of average productiviness can be represented as:

$$
\begin{aligned}
& \mathrm{SP}_{1}=\frac{Z}{x_{1}}=0.254 x_{1}^{-0.281} x_{2} 0.008 x_{3}^{0.004} \\
& S P_{2}=\frac{Z}{x_{2}}=0.254 x_{1}^{0.714} x_{2}^{-0.992} x_{3}^{0.004} \\
& \mathrm{SP}_{3}=\frac{Z}{x_{3}}=0.254 x_{1}^{0.719} x_{2}^{0.008} x_{3}^{-0.996}
\end{aligned}
$$

It appears that, the average productiviness of each seperately increased factor is decreasing at invariability of the remaining factors.

3. Similarily is represented the final productiviness (KP) by conversion of given formula $(\zeta)$ :

$$
K P_{1}=0.254(-0.281) x_{1}^{-1.281} x_{2}^{0.008} x_{3}^{0.004}
$$




$$
\begin{aligned}
\mathrm{KP}_{2} & =0.254(-0.992) \mathrm{x}_{1}^{0.719} \mathrm{x}_{2}^{-1.992} \mathrm{x}_{3}^{0.004} \\
\mathrm{KP}_{3} & =0.254(-0.996) \mathrm{x}_{1}^{0.719} \mathrm{x}_{2}^{0.008} \mathrm{x}_{3}^{-1.996}
\end{aligned}
$$

An analysis of given formulas proves that, the average and final productiviness of labour and investment in vessels, in accepted interrelation of factors at the increased disbursements, is decreasing much faster, than the mean and final productiviness in land disbursements.

4. The rate of production growth in relation to increase of particular factor, shall be decreasing, e.g. rate of production growth for employment (x3) appears from formula (5):

$$
\frac{\mathrm{d}^{2} \mathrm{x}}{\mathrm{dx_{3 } ^ { 2 }}}=(0.254)(0.004)(-0.996) \mathrm{x}_{1}^{0.719} \mathrm{x}_{2}^{0.008} \mathrm{x}_{3}^{-1.986}
$$

Apparently, the rate of production growth shall be decreasing. In relation to remaining factors, the rate of decreasing will be lowest at the increase of investments on land.

5. One of the main problems in a policy of investments is the intersubstitution of disbursements. For the considered structure of production in fisheries, as performula (6), the rate of substitution for investments on land and in vessels is:

$$
\frac{d x_{1}}{d_{2}}=\frac{0.719 x_{2}}{0.008 x_{1}}=\frac{90 x_{2}}{1 x_{1}}
$$

for investments on land and labour: $\frac{180 x_{3}}{1 x_{1}}$

and for investments in vessels and labour: $\frac{2 x_{3}}{1 x_{1}}$.

Thus, to maintain the production at invariable level in the existing structure of factors (66.5-672,5 units of investment in vessels are needed for substitution of $x_{1}$ investments on land).

Such ratio shall be different for various quantities of production; the quoted calculation relates to the theoritical limit quantities, i.e. minimum and maximum.

6. Basing on assumed function (1), the relation between production quantity and the output of labour may be expressed as:

$$
Z=A^{\frac{1}{1-\gamma}} x_{1} \propto x_{2} \beta\left(\frac{Z}{x_{3}}\right)^{\frac{\gamma}{\gamma-1}}
$$


and with substituted values of coefficients, represents :

$$
z=0.254^{1.004} x_{1}^{0.719} x_{2}^{0.008}\left(\frac{Z}{x_{n}}\right)-0.004
$$

Such equation indicates that an increase of labour output, with invariable remaining factors, may bear on production growth, within very limited degree.

The interrelation of production quantity and the absorbtion of investment funds for factor $x_{1}$ (investments on land) can be expressed as:

$$
Z=0.254^{3.559} x_{2}^{0.008} x_{3}^{0.004} \frac{(Z)}{x_{1}}-2.559
$$

Having denoted the coefficient of funds by $\mathrm{K}$, we obtain:

or

$$
\mathrm{K}=\frac{\mathrm{x}_{1}}{Z} \text {, expressed as }\left(\frac{Z}{x_{1}}\right)=\mathrm{K}^{-1}
$$

$$
Z=0.254^{3.559} x_{2}^{0.008} x_{3}^{0.004}\left(\mathrm{~K}_{i}\right)^{2.559}
$$

D i a g r a m 2

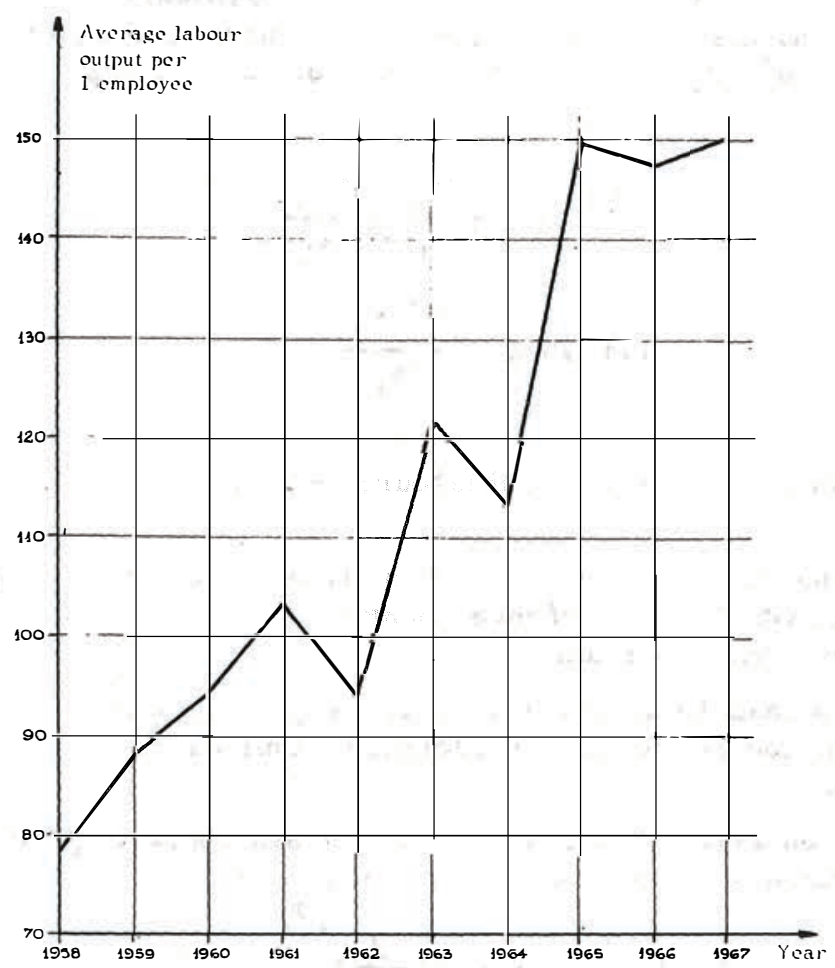

Average output of labour during the 1958-1967 
It may be seen from equation, that an increase of coefficient of fund absorbtion, bears positively on production growth.

Table 3 represents the index of labour output calculated in empiric data and at average productiviness of disbursement.

Average labour output and average productiviness

of total disbursements

\begin{tabular}{|c|c|c|}
\hline Year & $\begin{array}{l}\text { Labour output thou } \\
\text { ZI/1 man }\end{array}$ & $\begin{array}{l}\text { Mean productivin. of } \\
\text { disbursement } \mathrm{Zl} / \mathrm{Zl} \text {. }\end{array}$ \\
\hline 1958 & 78.1 & - \\
\hline 1959 & 88.1 & 1.5 \\
\hline 1960 & 94.2 & 1.6 \\
\hline 1961 & 103,2 & 3.8 \\
\hline 1962 & 94.0 & 3.3 \\
\hline 1963 & 121.6 & 2.8 \\
\hline 1964 & 113.1 & 4.1 \\
\hline 1965 & 149.8 & 3.1 \\
\hline 1966 & 147.3 & 2.6 \\
\hline 1967 & 150.1 & 3.1 \\
\hline
\end{tabular}

The obtained results are illustrated on diagram 2.

In interpretation of the given data it may be stated that, during the analysed period the output of labour in fisheries raised nearly 3-times. This should be assigned to an influence of absorbtion of investment funds. 


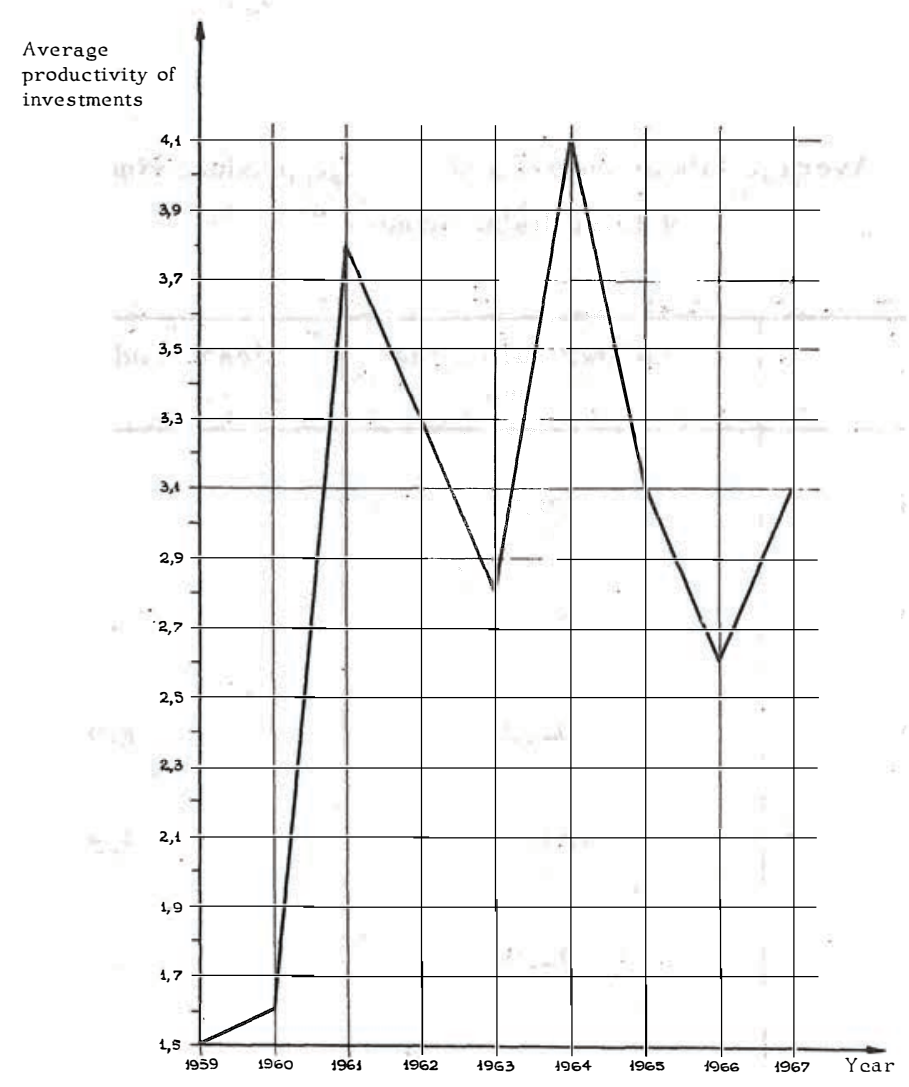

Average productivity of investments during the 1959-1967 with annual offset of investments

\section{CONCLUSIONS}

The estimating analysis of the result presented in this work, was performed at the following assumptions:

a) The function of production determines the relation between growth of production, investments and labour, as initiated on empiric data.

Any quantitive change interrelative to the particular factors, shall bear on estimation results, i.e. shall change the parameters of a function.

b) The same assumptions apply to an internal structure of disbursements seperately for each group and not only to the interrelation of total investments in vessels and on land. The high aggregation of data assumed for the calculation of production function, does not allow to differentiate how the structure 
of particular aggregated components influences the quantity of production.

c) Similiar assumptions mustalso be applied to the subsidiaries, which are immesurable in this calculation. Any change towards better exploit of them, shall bear on the result of estimation.

d) In its research, the work comprises the production of sphere of fisheries only and not the marketing turnovers.

Considerir.g the above assumptions as a starting point and accepting as correct the empirical data, the conclusions on estimating results of analysis may be formulated as follows:

1. The growth of production scale is decreasing in relation to an increase of its factors. Such result is conformed by the empiric determinations, which register a constant drop in relation to the accepted relative unit (e.g. BRT, $\mathrm{HP}$, or to other units), as the production increases.

2 . In the present interrelation of investments on land and in vessels, the coefficient of elasticity in investments on land is much higher than the remaining ones. It means, that the investments on land bear decidly on the growth of production. This is also conformed by the empiric observations that, any increase of investment in vessels at invariable relation to investment on land tends to minimize the fishing effects, and thus, makes the activities less-effective.

3. The previous conclusion is supported by the results of mean and final productivity of particular factors; it is further conformed by the results estimating the rate of production growth in relation to an increase of any particular factor. The coefficient of elasticity is high in the investment on land and low in investment in vessels and labour. An increase of the two remaining factors without increasing the investment on land, shall prove the low-effectiveness and indicate to the improper proportions in allocation of funds.

4. The estimation of inter-substitution between the investment on land and the expendentures in vessels prove in the final exemple, that any shortages in land-investment, in relation to investment in vessels, are of a very great importance. The potential reserves in production growth may be rised and ensure its proper going if the land-investments are increased adequately to investment in vessels. Under the presented heading, a change in relation of quantity in land investment to investment in vessels, shall give the base for rational action.

5. The estimation of interrelation between the quantity of production and the output of labour proves, that no production growth shall be achieved by increasing an output of labour without an increase of investments. The same estimation in relation to the absorbtion of funds proves that, an increase of labour output, in an aspect of the fund-absorption technical progress, shall positively influence the growth of production.

It appears from the empiric calculations that during the ten years, the index of labour output had risen twice. This allowed for an exploitation of the far fishing grounds within the economical reasons. It may therefore be safely concluded, that the growth of production infisheries and the possibility of it expansion, depends on an application of the funds-absorption technical progress and on the increase of investments. 


\section{REFERENCES}

Basiuk J., Maciej awski W., P i a s z c z yński W., 1968: Funkcja produkcji dla Polski w latach 1955-1965. „Zastosowanie metod matematycznych do analizy ekonomicznej". Zakład Badań Koniunktur i Cen Handlu Zagranicznego. Warszawa. (Function of production for Poland during the 1955-1965. "Application of mathematical methods for economical analysis". Foreign Trade Conjuncture and Price Research Institute. )

D u n a j e w s ki H., 1962: Struktura i stosowalność funkcji typu Cobb-Douglasa. "Ekonomista", 3. (Structure andapplication of Cobb-Douglas function).

Gó m u ł k a S., 1966: Równanie współczynnika kapitałochłonności i problem optymalnego sterowania. "Ekonomista", 4. (Equation of funds-absorption coefficient and the problems of optimal control).

L a n g e 0., 1966: Ekonomika polityczna. II. Warszawa. Political economy: .

M c E l w y F.W., 1967: Returns to Scale and Spacing of Isoquants Comment. "The American Economic Review".

P a je st ka J., 1961: Zatrudnienie i inwestycje a wzrost gospodarczy. Warszawa. (Labour and investments $\mathrm{v} / \mathrm{s}$ economical growth).

R a nis G., Fer J.C.H., 1961: A Theory of Economic Development. "The American Economic Review".

Stonad V., T l us ty Z., 1967: Odhad parametru substitucni produkcni funkcje Cobbowa-Douglasowa typu (aplikace metody na modolevani zakladnich ukazatelu ekonomickehe rozwoju CSRS w latach 1950-61). "Ekonomicko-Matematicky Obzor" 2. (Parameters arrangement of Cobb- Douglas coefficient applied methods on the pattern enterprises representing the economical in CSRS druing 1950-61).

W a 1 te r s A.A., 1963: Production and Cost Functions, An Econometrie Survey. "Econometrica". 31 .

\section{ZALEŻNOŚĆ WZROSTU PRODUKCJI OD INWESTYCJI WE FLOTĘ I INWESTYCJI LĄDOWYCH ORAZ ZATRUDNIENIA W PRZEMYŚLE RYBNYM}

\section{S.treszczenie}

Celem opracowania jest analiza układu czynników wzrostu produkcji w polskim przemyśle rybnym i zbadanie wpływu, jaki wywierają na kształtowanie się rozmiaru produkcji nakłady na inwestycje przemysłowe na lądzie, nakłady na zakup floty rybackiej oraz wielkość zatrudnienia. Jako model funkcji produkcji przyjęto model Cobb-Douglasa, najczęściej stosowany dla opi- 
sywania zależności między czynnikami produkcji a wielkością produkcji, która jest wyrażona wzorem (1). Oznaczając elastyczność produkcji względem nakładów otrzymuje się wzór (2), przy czym suma współczynników określa stopień jednorodności funkcji.

Średnią produktywność nakładów określa się dla poszczególnych nakładów wzorami (3), (4), (5). Stopę substytucji między nakładami określono wzorem $(6)$.

Dla przeprowadzenia analizy złożonej funkcji przyjęto dane statystyczne oparte na źródłach Zjednoczenia Gospodarki Rybnej i Minicterstwa Żeglugi za okres 1958-67, dotyczące produkcji przedsiębiorstw państwowych z pominięciem obrotu hurtowego i detalicznego. Wielkości nakładów inwestycyjnych podzielono na nakłady na flotęi inwestycje lądowe, które nie obejmują kwot wydatkowanych na budownictwo mieszkaniowe i socjalne. Liczby określające zatrudnienie obejmująilość zatrudnienia w przedsiębiorstwach przemysłowych. Tabl.1.

Po przeprowadzeniu estymacji metodą najmniejs zych kwadratów uzyskano wyniki przedstawione w tabl.2. Otrzymane wyniki korelacji między krzywą empiryczną a krzywą teoretyczną przedstawiono na rys.1. Na podstawie estymacji funkcja produkcji w omawianym okresie ma parametry, podane ve wzorze ad (1), przy czym suma wartości współczynników jest mniejsza od jedności, a najwyższy współczynnik elastyczności wykazująinwestycje lądowe.

Średnia produktywność ws zystkichnakładów (SP) maleje równolegle $z$ ich wzrostem, wzór ad (3). Podobnie zachowuje się produktywność krańcowa (KP), wzór ad (4), a tempo wzrostu produkcji w zależności od wzrostu poszczególnego czynnika będzie malejące, wzór ad (5), przy czym stopa substytucyjności nakładów kształtuje się zgodnie ze wzorem ad (б). Wzór (7) wskazuje na to, że wzrost kapitałochłonności inwestycji wpływa dodatnio na wzrost produkcji. Tab.3 przedstawia wydajność pracy i średnią produktywność nakładów.

Wnioski wyprowadzone na podstawie przedstawionych wyników badań wskazują na to, że w układzie proporcji nakładów w badanym okresie decydujące znaczenie na wzrost produkcji mająinwestycje lądowe, a powiększenie nakładów na flotę przy niezmienionym ich stosunku do inwestycji lądowych pociąga za sobą stałe pogarszanie się możliwości wykorzystania masy połowów i jest hamulcem dalszego ich powiększania.

ЗАВИСИМОСТЬ УВЕЛИЧЕНИЯ ПРОДУКЦИИ ОТ КАПИТАЛОВЛОЖЕНИЙ

В РЫБОЛОВЕЦКИЙ ФЛОТ И В МАТЕРИКОВЫЕ СООРУЖЕНИЯ, А ТАКЖЕ ОТ КОЛИЧЕСТВА РАБОЧЕЙ СИЛЫ В РЫБНОЙ ПРОМЫШЛЕННОСТИ 
рое оказывают на формирование масштабов производства затраты промыштенных капиталовложений на суше, затраты на приобретение рыболовецкого блота, а также количество рабочей силы. За модель функции продукции принята модель Кобб-Дугласа, чаще всего применяемая для описания зависимости между. факторами продукции и масштабами производства, которая выражена фоормулой (1). Определяя зависимость продукции от затрат, получаем формулу (2), -причём сумма коэф̆ф̆ицентов определяет степень однородности фоункции Средняя производительность затрат определяется для отдельных затрат формулами (3), (4), (5). Норма субститута между затратами определяется формулой (6).

Для. проведения анализа заданной функции взяты статистические - данные, основанные на материалах Рыбхозтреста и Министерства морского и речного фолота за 1958-67 г.Г•, касаюиеся производства государственных предприятий, исключая валовой и розничный оборот. Размеры затрат капиталовложений были разделены на затраты на фолот и на маттериковые капиталовложения, которые не охватывали сумм, использованных на жилищное и общественное строительство. Цифоры, определяющие рабочую силу, охватывают количество рабочей силы в промышленных предприятиях. (табл• 1 ).

После проведения оценки по методу наименьших квадратов получены результаты, представленные в табл. 2. Полученные результаты норреляции между эмпирической и теоретической кривыми представлены на рис. 1 . На основе оценки функция продукции за исследуемый период имеет параметры,приводимые в формуле (1), причём сумма значений коэфффициентов является меньше, чем единица, а наибольший коэф̌фициент эластичности дают материковые капиталовложения.

Средняя производительность всех затрат (СП) уменьшается параллельно с их увеличением, формула (3). Так же обстолт дело с конечной производительностью (КП), Формула (4), а темп роста продукции в зависимости от роста отдельных фоакторов будет уменьшаться, формула (5), причём норма субститутивности затрат формируется согласно формуле (6). Формула указывает на то, что рост ёмкости капиталовложений влияет на рост продукции. Табл. 3 представляет проивводительность труда и среднюю производительность затрат。

Выводы, сделанные на основе представленных результатов исследований, указывают на то, что в системе пропорций затрат в исследуемый период решаюее значение на рост продукции имеют материковые капиталовложения, а увеличение затрат на фолот при неизменном их соотношении с материковыми капиталовложениями влечёт за собой постоянное ухудшение возможностей использования улова и является тормозом дальнейшего их увеличения.

Address:

Prof.dr Andrzej Niegolewski

Katedra Ekonomiki Gospodarki Rybnej WSR

Szczecin, ul. Kazimierza Królewicza 4

Polsk'a- Poland

Received 8.IV.1969 